\title{
Problem-Based Learning in Phytochemistry Courses: Its' Effectiveness in Improving Medical Students' Critical Thinking Ability Viewed from Cognitive Style
}

\author{
Menap ${ }^{1}$, Faizul Bayani2 ${ }^{*}$, Saiful Prayogi ${ }^{3}$ \\ ${ }^{1}$ Master of Health Administration Study Program, Universitas Qamarul Huda Badaruddin Bagu, Jl. H. Badaruddin Bagu 83562, Indonesia \\ ${ }_{2}^{2}$ Pharmacy Study Program, Universitas Qamarul Huda Badaruddin Bagu, Jl. H. Badaruddin Desa Bagu 83562, Indonesia \\ ${ }^{3}$ Physic Education Study Program, Universitas Pendidikan Mandalika, Jl. Pemuda 59A Mataram 83125, Indonesia
}

DOI: $10.29303 /$ jppipa.v7iSpecialIssue.1124

\section{Article Info}

Received: October $28^{\text {th }}, 2021$

Revised: November $25^{\text {th }}, 2021$

Accepted: November 27th, 2021

\begin{abstract}
The implementation of the Problem-Based Learning (PBL) model for medical students has long been initiated to be integrated into the learning system and curriculum, however, empirical support for the application of the PBL model to medical students is still weak, becoming an obstacle. On the one hand, the need for critical thinking development among medical students is increasingly urgent, this is related to their future assignments in a more complex health care system that requires critical thinking ability. Our current study aims to evaluate the effectiveness of the problem-based learning (PBL) model on improving the critical thinking ability of medical students in terms of cognitive style. This study is an experimental study (one group pretest-posttest design) involving 21 medical students (medical students') in phytochemistry courses at one of the universities providing medical and nursing science programs in Indonesia. The study started by giving a cognitive style test using the GEFT (Group Embedded Figure Test) instrument to classify students into FD and FI cognitive styles, pretest, learning implementation using the PBL model (carried out for five meetings), and posttest. The pretest and posttest used a critical thinking ability test instrument in the form of an essay test. Descriptive and statistical analyzes were performed to evaluate the effectiveness of the PBL model. The results of the study show that the PBL model has been convincingly effective in improving students' critical thinking ability in phytochemistry courses for both FD/FI cognitive style modes. Based on these findings, we recommend the use of the PBL model in extensive and intensive learning to develop the critical thinking ability of medical students.
\end{abstract}

Keywords: Problem-Based Learning; Critical Thinking; Cognitive Style

Citation: $\quad$ Menap, M., Bayani, F., \& Prayogi, S. . (2021). Problem-Based Learning in Phytochemistry Courses: Its' Effectiveness in Improving Medical Students' Critical Thinking Ability Viewed from Cognitive Style. Jurnal Penelitian Pendidikan IPA, 7(SpecialIssue), 118-125. https://doi.org/10.29303/ippipa.v7iSpeciallssue.1124

\section{Introduction}

Critical literacy in the health and medical fields is a challenge for science teaching today (Rubinelli et al., 2021), and an important mission of the medical education planning system has led to critical thinking (Jafari et al., 2020). On the one hand, science as the front line in the education system must be prioritized, this is in line with the development of modern society as well as concerns about the decline in the quality of achievement and interest in science (LaForce et al., 2017). The current focus of science teaching is on developing students' critical thinking. Critical thinking is the most important skill to successfully face the 21st century

\footnotetext{
*Email: faizulbayani@uniqhba.ac.id
} 
(Prayogi et al., 2018a). These skills are achieved through a learning process. Furthermore, this mode of thinking is important for developing cognitive abilities and more effective information retention (Arifin et al., 2020). However, based on research in various fields such as science, it was found that students who graduated from various countries did not have the ability to compete on a global scale because they did not have the ability to think critically (Frijters et al., 2008). In the learning process in schools, science education has not been oriented towards habituation and improvement of critical thinking skills, and still focuses on low-level cognitive learning outcomes (Kurniahtunnisa et al., 2016).

Critical thinking is a predictor of a person's excellence in learning (Leest \& Wolbers, 2021). Critical thinking is a form of systematic and precise thinking, which follows the rules of logic and scientific reasoning (Lau, 2011). For this reason, critical thinking is one component of intelligence that is very calculated (Albergaria-Almeida, 2011). Critical thinking is even recognized as a mode of need in thinking as an asset in solving problems, and in learning the critical thinking training process is most effective when course material is presented with the right method (Berdahl et al., 2020). In the perspective of educational psychology, critical thinking is seen as "reasonable reflective thinking focused on deciding what to believe or do (Ennis, 2018). Based on previous studies, critical thinking indicators as the most intense cognitive dimension used to assess students' critical thinking ability are in the aspects of analysis, inference, evaluation, and decision making (Prayogi et al., 2018b; Prayogi \& Verawati, 2020; Verawati et al., 2018b; Prayogi \& Verawati, 2020; Verawati et al. al., 2019).

Considering the global conditions in this century, it seems that the transformation of students to be able to think critically is increasingly urgent (Aránguiz et al., 2020). Recently, a bibliometric study of 51 articles measured critical thinking in health and medical students, where the results showed that 48 articles reported students' critical thinking was at low levels (Jafari et al., 2020). Furthermore, this study recommends the importance of pedagogical interventions that lead students to be able to think critically. Therefore, the need for teaching critical thinking becomes a priority for learning at the higher education level. More extensively, this is called for by academics who support scholars as agents of change in critical thinking in society (Jenkins et al., 2018). It is widely acknowledged that the classical pedagogical model cannot develop students' critical thinking abilities. Finally, the pedagogical model offered to train critical thinking is a student-centered interactive learning model, one of which is Problem-based Learning (PBL) (Suhirman et al., 2020). This model has actually been proposed for a long time to be integrated into the teaching system and curriculum for health or medical students (Christopher et al., 2002; Kinkade, 2005), it's just that empirical support for the application of the PBL model to medical students is still weak. Therefore, its implementation effect needs to be further explored.

PBL is a student-centered learning model where a series of learning processes in PBL directs students to explore, apply knowledge, and integrate theory and practice (Savery, 2006). In problem-solving, a series of discrete tasks are completed by the learner to produce a knowledge product (Hung, 2011). PBL has long been used as a mode of active and constructivist learning through problem-solving in real-world contexts (Barrows, 1996). In its development, PBL is directed at increasing content knowledge, developing effective problem solving, creating independence and collaboration (Hmelo-Silver, 2004). Previous studies have found that PBL can increase students' interest and involvement in science (Cerezo, 2015; Mergendoller et al., 2006), PBL implementation can train students' creativity (Bell, 2010), problem-solving, and critical thinking skills (Ertmer et al., 2014; Prayogi \& Asy'ari, 2013), reflective thinking (Domínguez \& Jaime, 2010), communication and collaboration skills (Lou et al., 2011) and creating student independence in learning (Norman \& Schmidt, 2000).

It is widely recognized that practicing critical thinking requires good learning strategies and planning, this is not only done by teachers (instructors or lecturers) but also more needed by students. In this context, learning strategies are the key to determining the information processing of each learner (George et al., 2018). Moving on from the theory of self-efficacy (Bandura, 1982), we believe that information processing in each learner's learning is different, this depends on their cognitive style. This is supported by some previous research, where cognitive style is related to their acceptance of information processing (George et al., 2018), and information processing plays a role in individuals' acceptance of information and their behavior (Armstrong et al., 2012).

Cognitive style is identified with the level of individual consistency in how to understand, organize, and process information (Rayner \& Cools, 2011), and is believed to affect individual performance (Armstrong et al., 2012). Previous research has linked cognitive style to many fields and the most prominent is psychology (Cools et al., 2014). In the aspect of cognitive regulation, cognitive style plays a role in mediating individual cognitive abilities in learning and receiving information (Viator et al., 2020). Individual cognitive styles are categorized into field-dependent and field-independent (Witkin, 1967; Witkin et al., 1977). The connection with our current study is that we evaluate the effectiveness of 
the learning model that we conduct on students to improve critical thinking ability in terms of cognitive style.

This study specifically aims to evaluate the effectiveness of the problem-based learning (PBL) model on improving the critical thinking ability of medical students viewed from cognitive style.

\section{Method}

This study is an experimental study involving 21 medical students in phytochemistry courses at the University of Qamarul Huda Badaruddin Bagu, Indonesia. One group pretest-posttest design was used, where the effect of Problem-based Learning (PBL) was evaluated from the critical thinking ability scores on the pretest and post-test. The research design is presented in Table 1 . The study began with giving a cognitive style test using the GEFT (Group Embedded Figure Test) instrument (Witkin et al., 1977), pretest, implementation of learning using the PBL model (carried out for five meetings on phytochemistry material), and posttest. Next, the analysis of the results is carried out.

Table 1. Research design

\begin{tabular}{lllll}
\hline Sampling & $\begin{array}{l}\text { Cognitive } \\
\text { style test }\end{array}$ & $\begin{array}{l}\text { Pretest } \\
\text { (O1) }\end{array}$ & $\begin{array}{l}\text { Treatment } \\
(\mathrm{X})\end{array}$ & $\begin{array}{l}\text { Posttest } \\
(\mathrm{O} 2)\end{array}$ \\
\hline $\mathrm{N}=21$ & GEFT & $\begin{array}{l}\text { CT Essay } \\
\text { Test }\end{array}$ & PBL Model & $\begin{array}{l}\text { CT Essay } \\
\text { Test }\end{array}$ \\
\hline
\end{tabular}

The critical thinking instrument consists of 8 items in the form of essays with indicators of analysis, inference, decision making, and evaluation (Prayogi \& Verawati, 2020). This critical thinking question is presented at the pretest and posttest. The critical thinking score uses a graded scale starting from +3 (maximum score) and -1 (minimum score). Analysis of individual critical thinking scores was averaged and categorized into very critical, critical, moderately critical, less critical, and uncritical criteria. This scoring and categorization system was adapted from a previous study (Verawati et al., 2019) as presented in Table 2.

Table 2. Criteria for critical thinking ability

\begin{tabular}{lll}
\hline No & Score range & Category \\
\hline 1 & $X>17.6$ & Very critically \\
2 & $11.2<X \leq 17.6$ & Critically \\
3 & $4.8<X \leq 11.2$ & Enough critically \\
4 & $-1.6<X \leq 4.8$ & Less critically \\
5 & $X \leq-1.6$ & Not critically \\
\hline
\end{tabular}

Increased scores of students' critical thinking ability were analyzed using the n-gain equation with the criteria of high $(>0.7)$, moderate $(0.3-0.7)$, and low $(<0.3)$ (Hake, 1999).

Statistical data analysis (inferential statistics) was conducted to analyze student critical thinking ability test data. The test used is the t-test which aims to examine the impact of the learning model on critical thinking ability. The rejection criterion is $\mathrm{H}_{0}$ if the statistical significance or $\mathrm{p}$-value of the $\mathrm{t}$-test is less than 0.05 . If $\mathrm{H}_{0}$ is rejected then $\mathrm{H}_{1}$ is accepted, or vice versa. The condition before the $\mathrm{t}$-test is that the data is normally distributed with the criteria if the significance ( $p$-value) is greater than 0.05 . All data analysis statistically using SPSS 23.0 software.

\section{Results and Discussion}

Cognitive style test results are presented in Table 3. Referring to the categorization (Witkin et al., 1977), in the score range $0-11$ individuals are categorized into Field Dependent (FD) cognitive style, and in the score range 12-18 individuals are categorized into Field Independent (FI) cognitive style. In this score range, the results show that of the 21 students as the research sample, 12 students were categorized into the FD cognitive style and 9 students were categorized into the FI. The tendency is that there are more students in the FD category than FI (see Table 3). The FI cognitive style is a characteristic of individuals who are able to analyze in separating elements from their context more analytically, while the FD cognitive style is a characteristic of individuals who process information globally so that their perceptions are easily affected by environmental changes (Purnomo et al., 2017). The results of this study are in line with the findings of previous studies, that the tendency of students' cognitive styles to vary and relatively balanced between FD and FI cognitive styles (Verawati et al., 2021).

Table 3. Cognitive style test results

\begin{tabular}{llll}
\hline No & Cognitive style & Score & $\mathrm{n}(21)$ \\
\hline 1 & Field Dependent & $0-11$ & 12 \\
2 & Field Independent & $12-18$ & 9 \\
\hline
\end{tabular}

The measurement of each individual's critical thinking based on cognitive style shows the results as presented in Table 4. Each student's critical thinking ability is measured before learning using PBL (as pretest) and after learning using PBL (as posttest). 
Table 4. Results of measuring students' CT ability for each cognitive style

\begin{tabular}{|c|c|c|c|c|c|c|c|}
\hline \multirow{2}{*}{ No } & \multirow{2}{*}{ Cognitif Style } & \multicolumn{2}{|l|}{ Pretest } & \multicolumn{2}{|l|}{ Posttest } & \multirow{2}{*}{ n-gain } & \multirow{2}{*}{ Criteria } \\
\hline & & CT score & Criteria & CT score & Criteria & & \\
\hline 1 & FI & -3 & Not critically & 18 & Very critically & 0.78 & High \\
\hline 2 & FI & 0 & Less critically & 16 & Critically & 0.67 & Moderate \\
\hline 3 & FI & -4 & Not critically & 14 & Critically & 0.64 & Moderate \\
\hline 4 & FI & -2 & Not critically & 13 & Critically & 0.58 & Moderate \\
\hline 5 & FI & -1 & Less critically & 16 & Critically & 0.68 & Moderate \\
\hline 6 & FI & -1 & Less critically & 15 & Critically & 0.64 & Moderate \\
\hline 7 & FI & -5 & Not critically & 15 & Critically & 0.70 & High \\
\hline 8 & FI & -3 & Not critically & 13 & Critically & 0.60 & Moderate \\
\hline 9 & FI & -2 & Not critically & 14 & Critically & 0.62 & Moderate \\
\hline 10 & FD & -3 & Not critically & 15 & Critically & 0.67 & Moderate \\
\hline 11 & FD & 0 & Less critically & 13 & Critically & 0.54 & Moderate \\
\hline 12 & FD & -1 & Less critically & 15 & Critically & 0.64 & Moderate \\
\hline 13 & FD & -4 & Not critically & 19 & Critically & 0.82 & High \\
\hline 14 & FD & 2 & Less critically & 12 & Critically & 0.45 & Moderate \\
\hline 15 & FD & -5 & Not critically & 17 & Critically & 0.76 & High \\
\hline 16 & FD & -5 & Not critically & 15 & Critically & 0.69 & Moderate \\
\hline 17 & FD & -4 & Not critically & 22 & Very critically & 0.93 & High \\
\hline 18 & FD & -2 & Not critically & 18 & Very critically & 0.77 & High \\
\hline 19 & FD & 0 & Less critically & 15 & Critically & 0.63 & Moderate \\
\hline 20 & FD & -2 & Not critically & 13 & Critically & 0.58 & Moderate \\
\hline 21 & FD & -1 & Less critically & 18 & Very critically & 0.76 & High \\
\hline \multicolumn{2}{|c|}{ Averages } & -2.20 & Not critically & 15.45 & Critically & 0.67 & Moderate \\
\hline
\end{tabular}

Measurement of students' critical thinking ability for each cognitive style has been carried out (see Table 4). From the 12 students classified as FD, the results of the pretest showed as many as 7 students with not critically criteria and 5 students with less critically criteria. In the posttest, it was found that 9 students had critical criteria and the rest (3 students) were very critical. On the one hand, in the group of students belonging to FI (9 students), in the pretest, it was found that 6 students had no critical criteria and 3 students were less critical. In the posttest, it was found that 8 students had critical criteria and only 13 students were very critical.

The calculation of the average score of students' critical thinking has been carried out, where the results of the pretest show that students are in the criteria of not critically and less critically, while the posttest with critically and very critically criteria. The analysis of the increase in the critical thinking ability score of each student has been measured, and the results show the criteria for increasing the score are in the moderate and high categories. In general, the average score of students' critical thinking ability in the pretest is -2.20 with the criteria not critically, and after the implementation of the PBL model, the average posttest score is 15.45 with the critical criteria, with an n-gain score of 0.67 with moderate criteria. Descriptive analysis with average critical thinking scores based on two categories of cognitive style (FI/FD) is presented in Table 5.

The critical thinking score for the FD cognitive style $(\mathrm{N}=12)$ was -2.08 in the pretest with no critical criteria, and after the implementation of the PBL model, it increased to 16.00 on the posttest with critical criteria ( $n$ gain of 0.69 with moderate criteria). For the FI cognitive style $(\mathrm{N}=9)$ the pretest score was -2.33 with not critically criteria, and 14.89 for posttest with critical criteria (n gain of 0.66 with moderate criteria). Overall, the increase in students' critical thinking scores was on the same criteria, from not critically to critically.

Table 5. Critical thinking scores for each cognitive style

\begin{tabular}{lllllllll}
\hline \multirow{2}{*}{ No } & \multirow{2}{*}{ Cognitive Style } & \multirow{2}{*}{$\mathrm{N}$} & \multicolumn{2}{l}{ Pretest } & Posttest & n-gain & \multirow{2}{*}{ Criteria } \\
\cline { 4 - 7 } & & CT score & Criteria & CT score & Criteria & & \\
\hline 1 & FD & 12 & -2.08 & Not critically & 16.00 & Critically & 0.69 & Moderate \\
2 & FI & 9 & -2.33 & Not critically & 14.89 & Critically & 0.66 & Moderate \\
Average & & -2.20 & Not critically & 15.45 & Critically & 0.67 & Moderate \\
\hline
\end{tabular}

Statistically, the results of measuring critical thinking ability in Table 5 need to be tested. The results of the different test (t-test) of students' critical thinking ability based on the FD/FI cognitive style as presented in Table 6. As a prerequisite for testing, homogeneity and normality tests were carried out as presented in 
Table 6 . The results showed that the data variance was homogeneous and normally distributed (sig. > 0.05).

Table 6. The results of the homogeneity and normality test based on cognitive style

\begin{tabular}{llll}
\hline Homogeneity test & & Normality test & \\
\hline Levene statistic & Sig. & Kol-Smir. statistic & Sig. \\
\hline 1.168 & 0.293 & 0.960 & 0.200 \\
\hline
\end{tabular}

Table 7. The results of the different test (t-test) of students' CT ability based on cognitive style

\begin{tabular}{llllll}
\hline & $\begin{array}{l}\text { Sum of } \\
\text { Squares }\end{array}$ & df & $\begin{array}{l}\text { Mean } \\
\text { Square }\end{array}$ & F & Sig. \\
\hline Between Groups & 0.321 & 1 & 0.321 & 0.084 & 0.775 \\
Within Groups & 72.917 & 19 & 3.838 & & \\
Total & 73.238 & 20 & & & \\
\hline
\end{tabular}

The results of the different test (Table 7) show a significance value $>0.05$. In accordance with the criteria for testing the hypothesis, it can be interpreted that there is no significant difference in students' critical thinking ability between the two FD/FD cognitive styles in the posttest after the implementation of the PBL model. This means that the PBL model can train students' critical thinking ability with FD and FI cognitive styles.

The PBL model has been convincingly effective in improving students' critical thinking ability in phytochemistry courses. The conduction of the PBL model in medical students deserves consideration for its widespread use, especially to improve students' critical thinking ability (for both FD/FI cognitive style modes). The conduct of PBL in the learning system and curriculum at medicine colleges helps prepare prospective graduates with the knowledge and skills needed, it trains medical students in more complex health care systems (Hoffman et al., 2006). The implementation of the PBL model in medical students has long been initiated to be integrated into the learning system and curriculum (Christopher et al., 2002; Kinkade, 2005), however, empirical support for the application of the PBL model to medical students is still weak, becoming an obstacle. Finally, the findings in this study should be a reinforcing factor that the PBL model for medical students, especially in phytochemistry courses, has been able to improve their critical thinking ability.

Pedagogy in PBL was developed as a platform to develop problem solving skills, independent learning and the ability to work in teams (Radcliffe \& Kumar, 2016). The findings from our study, it is precisely the PBL model can improve critical thinking ability. In learning, the PBL model conducts in five phases of learning, namely: student orientation to problems, organizing students to learn, guiding group investigations, developing and presenting work, and analyzing and evaluating problem solving processes.

The interaction built in the PBL Model is studentcentered learning, this emphasizes the activity and effectiveness of discussion and group work to identify effective solutions in problem solving (Luo, 2019). In our study, the interaction between individuals in a group directly motivates students in learning, and this is a strong asset to build positive learning according to the expected goals. In a previous study it was found that positive perceptions of the scaffolding approach in PBL contributed to building effective learning (Beagon et al., 2019). The presentation of theory and learning experiences with the principle of positive interaction built into PBL has an impact on superior educational outcomes (Radcliffe \& Kumar, 2016).

Finally, based on the findings in our current study, we recommend applying the PBL model more intensively to medical students, this is to train them to work together, gain the required knowledge and skills, and above all to gain critical thinking, which helps them in more complex health care systems in many cases found.

\section{Conclusion}

The results of the study show that the PBL model has been convincingly effective in improving students' critical thinking ability in phytochemistry courses for both FD/FI cognitive style modes. Based on these findings, we recommend the use of the PBL model in extensive and intensive learning to develop critical thinking ability of medical students.

\section{References}

Albergaria-Almeida, P. (2011). Critical Thinking, Questioning and Creativity as Components of Intelligence. Procedia - Social and Behavioral Sciences, 30, 357-362. https://doi.org/10.1016/j.sbspro.2011.10.070

Aránguiz, P., Palau-Salvador, G., Belda, A., \& Peris, J. (2020). Critical Thinking Using Project-Based Learning: The Case of The Agroecological Market at the "Universitat Politècnica de València." Sustainability, 12(9), 3553. https://doi.org/10.3390/su12093553

Arifin, S., Setyosari, P., Sa'dijah, C., \& Kuswandi, D. (2020). The effect of problem based learning by cognitive style on critical thinking skills and student retention. Journal of Technology and Science Education, 10(2), 271. https://doi.org/10.3926/jotse.790

Armstrong, S. J., Cools, E., \& Sadler-Smith, E. (2012). Role of Cognitive Styles in Business and 
Management: Reviewing 40 Years of Research. International Journal of Management Reviews, 14(3), 238-262. https://doi.org/10.1111/j.14682370.2011.00315.x

Bandura, A. (1982). Self-efficacy mechanism in human agency. American Psychologist, 37(2), 122-147. https://doi.org/10.1037/0003-066X.37.2.122

Barrows, H. S. (1996). Problem-based learning in medicine and beyond: A brief overview. New Directions for Teaching and Learning, 1996(68), 3-12. https://doi.org/10.1002/tl.37219966804

Beagon, Ú., Niall, D., \& Ní Fhloinn, E. (2019). Problembased learning: Student perceptions of its value in developing professional skills for engineering practice. European Journal of Engineering Education, 44(6),

850-865. https://doi.org/10.1080/03043797.2018.1536114

Bell, S. (2010). Project-Based Learning for the 21st Century: Skills for the Future. The Clearing House: A Journal of Educational Strategies, Issues and Ideas, 83(2), 39-43. https://doi.org/10.1080/00098650903505415

Berdahl, L., Hoessler, C., Mulhall, S., \& Matheson, K. (2020). Teaching Critical Thinking in Political Science: A Case Study. Journal of Political Science Education, 1-16. https://doi.org/10.1080/15512169.2020.1744158

Cerezo, N. (2015). Problem-Based Learning in the Middle School: A Research Case Study of the Perceptions of At-Risk Females. RMLE Online, 27(1),

1-13. https://doi.org/10.1080/19404476.2004.11658164

Christopher, D. F., Harte, K., \& George, C. F. (2002). The implementation of Tomorrow's Doctors: The implementation of Tomorrow's Doctors. Medical Education, 36(3), 282-288. https://doi.org/10.1046/j.1365-2923.2002.01152.x

Cools, E., Armstrong, S. J., \& Verbrigghe, J. (2014). Methodological practices in cognitive style research: Insights and recommendations from the field of business and psychology. European Journal of Work and Organizational Psychology, 23(4), 627641.

https://doi.org/10.1080/1359432X.2013.788245

Domínguez, C., \& Jaime, A. (2010). Database design learning: A project-based approach organized through a course management system. Computers $\mathcal{E} \quad$ Education, 55(3), 1312-1320. https://doi.org/10.1016/j.compedu.2010.06.001

Ennis, R. (2018). Critical Thinking Across the Curriculum: A Vision. Topoi, 37(1). 165-184. doi: https://doi.org/10.1007/s11245-016-9401-4

Ertmer, P. A., Schlosser, S., Clase, K., \& Adedokun, O. (2014). The Grand Challenge: Helping Teachers Learn/Teach Cutting-Edge Science via a PBL
Approach. Interdisciplinary Journal of Problem-Based Learning, 8(1), Article 1. https://doi.org/10.7771/1541-5015.1407

Frijters, S., ten Dam, G., \& Rijlaarsdam, G. (2008). Effects of dialogic learning on value-loaded critical thinking. Learning and Instruction, 18(1), 66-82. https://doi.org/10.1016/j.learninstruc.2006.11.00 $\underline{1}$

George, B., Desmidt, S., Cools, E., \& Prinzie, A. (2018). Cognitive styles, user acceptance and commitment to strategic plans in public organizations: An empirical analysis. Public Management Review, 20(3), 340-359. https://doi.org/10.1080/14719037.2017.1285112

Hake, R., R. (1999). Analyzing change/gain scores. Indiana University: Woodland Hills, CA - USA.

Hmelo-Silver, C. E. (2004). Problem-Based Learning: What and How Do Students Learn? Educational Psychology Review, 16(3), 235-266. https://doi.org/10.1023/B:EDPR.0000034022.164 $\underline{70 . \mathrm{f} 3}$

Hoffman, K., Hosokawa, M., Blake, R., Headrick, L., \& Johnson, G. (2006). Problem-Based Learning Outcomes: Ten Years of Experience at the University of Missouri???Columbia School of Medicine: Academic Medicine, 81(7), 617-625. https://doi.org/10.1097/01.ACM.0000232411.97 399.c6

Hung, W. (2011). Theory to reality: A few issues in implementing problem-based learning. Educational Technology Research and Development, 59(4), 529-552. https://doi.org/10.1007/s11423011-9198-1

Jafari, F., Azizi, S. M., Soroush, A., \& Khatony, A. (2020). Critical Thinking Level among Medical Sciences Students in Iran. Education Research International, 2020, 1-18. https://doi.org/10.1155/2020/1348365

Jenkins, K., Sovacool, B. K., \& McCauley, D. (2018). Humanizing sociotechnical transitions through energy justice: An ethical framework for global transformative change. Energy Policy, 117, 66-74. https://doi.org/10.1016/j.enpol.2018.02.036

Kinkade, S. (2005). A Snapshot of the Status of ProblemBased Learning in U. S. Medical Schools, 2003???04: Academic Medicine, 80(3), 300-301. https://doi.org/10.1097/00001888-200503000$\underline{00021}$

Kurniahtunnisa, K., Dewi, N. K., \& Utami, N. R. (2016). Pengaruh model problem-based learning terhadap kemampuan berpikir kritis siswa materi sistem ekskresi. Journal of Biology Education, 5(3), 310-318. https://doi.org/10.15294/ibe.v5i3.14865 [Indonesian] 
LaForce, M., Noble, E., \& Blackwell, C. (2017). ProblemBased Learning (PBL) and Student Interest in STEM Careers: The Roles of Motivation and Ability Beliefs. Education Sciences, 7(4), 92. https://doi.org/10.3390/educsci7040092

Lau, Joe. Y. F. (2011). An Introduction to Critical Thinking and Creativity: Think More, Think Better. John Wiley \& Sons, Inc. https://doi.org/10.1002/9781118033449

Leest, B., \& Wolbers, M. H. J. (2021). Critical thinking, creativity and study results as predictors of selection for and successful completion of excellence programmes in Dutch higher education institutions. European Journal of Higher Education, 11(1), 29-43. https://doi.org/10.1080/21568235.2020.1850310

Lou, S.-J., Shih, R.-C., Ray Diez, C., \& Tseng, K.-H. (2011). The impact of problem-based learning strategies on STEM knowledge integration and attitudes: An exploratory study among female Taiwanese senior high school students. International Journal of Technology and Design Education, 21(2), 195-215. https://doi.org/10.1007/s10798-010-9114-8

Luo, Y.-J. (2019). The influence of problem-based learning on learning effectiveness in students of varying learning abilities within physical education. Innovations in Education and Teaching International, 56(1), 3-13. https://doi.org/10.1080/14703297.2017.1389288

Mergendoller, J. R., Maxwell, N. L., \& Bellisimo, Y. (2006). The Effectiveness of Problem-Based Instruction: A Comparative Study of Instructional Methods and Student Characteristics. Interdisciplinary Journal of Problem-Based Learning, 1(2), Article 2. https://doi.org/10.7771/15415015.1026

Norman, G. R., \& Schmidt, H. G. (2000). Effectiveness of problem-based learning curricula: Theory, practice and paper darts. Medical Education, 34(9), 721-728. $\quad$ https://doi.org/10.1046/j.13652923.2000.00749.x

Prayogi, S., \& Asy'ari, M. (2013). Implementasi model PBL (Problem-based Learning) untuk meningkatkan hasil belajar dan kemampuan berpikir kritis siswa. Prisma Sains: Jurnal Pengkajian Ilmu dan Pembelajaran Matematika dan IPA IKIP Mataram, 1(1), 80. https://doi.org/10.33394/j-ps.v1i1.521

[Indonesian]

Prayogi, S., \& Verawati, N. N. S. P. (2020). The Effect of Conflict Cognitive Strategy in Inquiry-based Learning on Preservice Teachers' Critical Thinking Ability. Journal of Educational, Cultural and Psychological Studies (ECPS Journal), 0(21), 2741. https://doi.org/10.7358/ecps-2020-021-pray
Prayogi, S., Yuanita, L., \& Wasis. (2018a). CriticalInquiry-Based-Learning: Model of Learning to Promote Critical Thinking Ability of Pre-service Teachers. Journal of Physics: Conference Series, 947, $012013 . \quad$ https://doi.org/10.1088/1742$\frac{6596 / 947 / 1 / 012013}{}$

Prayogi, S., Yuanita, L., \& Wasis. (2018b). Critical Inquiry Based Learning: A Model of Learning to Promote Critical Thinking Among Prospective Teachers of Physic. Journal of Turkish Science Education, 15(1), 43-56.

Purnomo, R. C., Sunardi, S., \& Sugiarti, T. (2017). Profil Kreativitas dalam Pemecahan Masalah Matematika Ditinjau dari Gaya Kognitif Field Independent (FI) dan Field Dependent (FD) Siswa Kelas VIII A SMP Negeri 12 Jember. Jurnal Edukasi, 4(2), 9. https://doi.org/10.19184/jukasi.v4i2.5203 [Indonesian]

Radcliffe, P., \& Kumar, D. (2016). Is problem-based learning suitable for engineering? Australasian Journal of Engineering Education, 21(2), 81-88. https://doi.org/10.1080/22054952.2017.1351131

Rayner, S., \& Cools, E. (2011). Style Differences in Cognition, Learning, and Management: Theory, Research and Practice. Routledge.

Rubinelli, S., Ort, A., Zanini, C., Fiordelli, M., \& Diviani, N. (2021). Strengthening Critical Health Literacy for Health Information Appraisal: An Approach from Argumentation Theory. International Journal of Environmental Research and Public Health, 18(13), 6764. https://doi.org/10.3390/ijerph18136764

Savery, J. R. (2006). Overview of Problem-based Learning: Definitions and Distinctions. Interdisciplinary Journal of Problem-Based Learning, 1(1), Article 1. https://doi.org/10.7771/15415015.1002

Suhirman, S., Yusuf, Y., Muliadi, A., \& Prayogi, S. (2020). The Effect of Problem-Based Learning with Character Emphasis toward Students' HigherOrder Thinking Skills and Characters. International Journal of Emerging Technologies in Learning (IJET), 15(06), 183. https://doi.org/10.3991/ijet.v15i06.12061

Verawati, N. N. S. P., Hikmawati, \& Prayogi, S. (2021). The Effectiveness of reflective-inquiry learning model to improve preservice-teachers' critical thinking ability viewed from cognitive style. Journal of Physics: Conference Series, 1747(1), 012010. https:// doi.org/10.1088/17426596/1747/1/012010

Verawati, N. N. S. P., Prayogi, S., Gummah, S., Muliadi, A., \& Yusup, M. Y. (2019). The Effect of ConflictCognitive Strategy in Inquiry Learning towards Pre-Service Teachers' Critical Thinking Ability. 
Jurnal Pendidikan IPA Indonesia, 8(4), Article 4. https://doi.org/10.15294/jpii.v8i4.21002

Viator, R. E., Harp, N. L., Rinaldo, S. B., \& Marquardt, B. B. (2020). The mediating effect of reflectiveanalytic cognitive style on rational thought. Thinking $\mathcal{E}$ Reasoning, 26(3), 381-413. https://doi.org/10.1080/13546783.2019.1634151

Witkin, H. A. (1967). A Cognitive-Style Approach to Cross-Cultural Research. International Journal of Psychology,

2(4), 233-250. https://doi.org/10.1080/00207596708247220

Witkin, H. A., Moore, C. A., Goodenough, D., \& Cox, P. W. (1977). Field-Dependent and FieldIndependent Cognitive Styles and Their Educational Implications. Review of Educational Research, 47(1), 1-64. https://doi.org/10.3102/00346543047001001 